\title{
Anti-Inflammatory Effect of Ethanolic Extract of Curcuma aeruginosa Roxb Rhizome, Morinda Citrifolia Fruit and Apium graveolens Leaf on Lipopplysaccharide-induce RAW 264.7 Cell Lines
}

\author{
Siska Andrina*, Churiyah, Nuralih \\ Center of Pharmaceutical and Medical Technology, \\ Agency for the Assessment and Application of Technology, Indonesia
}

\begin{abstract}
Curcuma aeruginosa Roxb., Morinda citrifolia and Apium graveolens are Indonesian plants which have been used in traditional medicine as an antihelmintic, antimicrobial, antiinflammation and antioxidant. In this study, the antiinflammatory activity of Curcuma aeruginosa Roxb. rhizome, Morinda citrifolia fruit and Apium graveolens leaf extract was investigated. All of extract was prepared by maceration with ethanol $70 \%$ and treated for antiinflammatory effect by using inducible-nitric oxide secretion measurement on lipopolysaccharide (LPS) - induce macrophage RAW 264.7 cells. We used three concentration of Curcuma aeruginosa Roxb. rhizome and Apium graveolens leaf extract at 25 ppm; 50 ppm; 100 ppm while for Morinda citrifolia fruit extract with 50 ppm; 100 ppm; 200 ppm. This study revealed that rhizome of Curcuma aeruginosa Roxb. and fruit of Morinda citrifolia extract inhibited inducible-nitric oxide synthesis with highest value of $84.2 \%$ at $25 \mathrm{ppm}$ and $85.71 \%$ at $100 \mathrm{ppm}$ in cells. However, leaf of Apium graveolens extract showed low inhibition with highest values of $18.85 \%$ at 100 ppm. This study demonstrates the potential of Curcuma aeruginosa Roxb. rhizome and Morinda citrifolia fruit as antiinflammatory agents.
\end{abstract}

Keywords: Curcuma aeruginosa Roxb., Apium graveolens, Morinda citrifolia, antiinflammation, inducible-nitric oxide, lipopolysaccharide-induce macrophage RAW 264.7 cells

\section{INTRODUCTION}

Inflammation is one of self-defense mechanisms in body which is characterized by redness, pain, swelling and a sensation of heat. The inflammatory responses play an important role in host survival although it can also lead to chronic inflammatory diseases such as asthma (Cragg and Newman, 2008), cancer (Hendra, et al., 2011), rheumatoid arthritis (Hsieh, et al., 2007), Crohn's disease (Moncada, et al., 1991) and ulcerative colitis (UC) (MacMicking, et al., 1997). The production of inflammatory cytokines such as interleukin-6 (IL6), tumor necrosis factor-alpha (TNF-alpha), and other inflammatory mediators including nitric oxide (NO) and prostaglandin E2 (PGE) will arise immediately. Nitric oxide (NO), which is synthesized by nitric oxide synthase (NOS) from L-arginine using
NADPH and molecular oxygen, is a short-lived free radical and an intercellular messenger produced by a variety of mammalian cells, which include macrophages, neutrophils, platelets, fibroblasts, endothelium, neuronal, and smooth muscle cells. NO mediates a variety of biological actions ranging from vasodilatation, neurotransmission, inhibition of platelet adherence and aggregation, as well as the macrophage- and neutrophil-mediated killing of pathogens (Moncada, et al., 1991, MacMicking, et al., 1997; Oh, et al., 2008). Chronic inflammation and infections lead to the up-regulation of a series of enzymes and signaling proteins in affected tissues and cells. The inducible forms of NOS are the most important.

*Corresponding author e-mail: siska.a.kusumastuti@gmail.com 
Plants have formed the basis of sophisticated traditional medicine systems that have been in existence for thousands of years. These plant based medicinal systems continue to play an essential role In health care today, and it has been estimated by the World Health Organization that Approximately 80\% of the world's inhabitants rely mainly on traditional medicines for primary health care (Cragg and Newman, 2008; Hsieh, et al., 2007). Indonesia is one of rich country that have more a thousand plants growing in distributed areas of Indonesia. Most plants have been used by local people as a traditional medicine or jати by history, as example Curcuma aeruginosa Roxb. which originated from South East Asia including Indonesia. Curcuma aeruginosa Roxb grows throughout the year in tropical areas reaching a height of around $1.5 \mathrm{~m}$ which has dark rhizome with unique odor. Rhizome of Curcuma aeruginosa Roxb. have been used as a traditional medicine or jати by Indonesian people to treat many disease such as inflammation, fungi and infection of bacteria. Morinda citrofolia is one of famous plant from Indonesia. Leaf of Morinda citrofolia have been used as a medicine in many years ago as an analgetic, immunostimulant, antiinflammation and also antibacterial. Leaf of Morinda citrofolia has been proven being as anticancer agent because its potential to ihibit some regulatory gene of cancer cells. Apium graveolens is originated from South of Europe and has distributed all of the world. Apium graveolens or celery herbs is used by local people as one of food ingredients and also as a medicine. As a medicine, Apium graveolens is used to reduce the blood pressure, paint killer and inducer of appetite. This study aims to investigate Indonesian plants for the inhibitory activity toward Nitric Oxide production by measuring its production in LPSstimulated macrophage RAW 264.7 cell line.

\section{MATERIALS AND METHODS}

\section{Plant and Extract Preparation}

The plants were collected from Serpong, Banten, Indonesia. Plant materials were air-dried, grounded and extracted three times with $70 \%$ ethanol at room temperature. The filtrates were concentrated under reduced pressure, and stored in a closed container until treatment.

\section{Cell Culture}

Murine macrophage RAW 264.7 cells were obtained from KRIBB Korea. They were cultured in Roswell Park Memorial Institute medium (RPMI) containing $2 \mathrm{mM}$ glutamine, $10 \mathrm{mM} \quad 4-[2$ hydroxyethyl]1-piperazineethanesulfonic acid (HEPES), penicillin (Gibco) (100 units $/ \mathrm{mL})$, streptomycin (Gibco) $(100 \mu \mathrm{g} / \mathrm{mL})$ and $10 \%$ Fetal Bovine Serum (Gibco). Cells were cultured at $37^{\circ} \mathrm{C}$ in a humidified incubator with $5 \% \mathrm{CO}_{2}$.

\section{MTT Assay}

Cells were cultured in 96-well plates for 24 hr. After 24 hours, plant extracts at concentrations of $200 ; 100 ; 50 ; 25 ; 12.5 ; 6.25 \mu \mathrm{g} / \mathrm{mL}$ was added into the well in triplicate then incubation overnight. The next day, 3-(4,5dimethylthiazol-2-yl)-2,5diphenyltetrazoliu bromide or MTT (Sigma) was added to the medium for 4 hours followed by SDS with $\mathrm{HCl} 0.01 \mathrm{~N}$ to dissolve the formazan crystals. Incubate for 24 hours and then measured with microplate reader with absorbance at $540 \mathrm{~nm}$. The percentage of dead cells was determined related to control group.

\section{Nitric Oxide Assay}

The nitric oxide assay was performed as described previously with slight modification (Yoon, et al., 2009). After pre-incubation of RAW 264.7 cells $\left(5 \times 10^{5}\right.$ cells $\left./ \mathrm{mL}\right)$ with LPS (Sigma) $2 \mu \mathrm{g} / \mathrm{mL}$ for $24 \mathrm{~h}$, the quantity of nitrite in the culture medium was measured as an indicator of $\mathrm{NO}$ production. Amounts of nitrite, a stable metabolite of NO, were measured by using Griess reagent ( $1 \%$ sulfanilamide and $0.1 \%$ naphthylethylenediamine dihydrochloride in $2.5 \%$ phosphoric acid). Briefly, $100 \mu \mathrm{L}$ of cell culture medium was mixed with $100 \mu \mathrm{L}$ of Griess reagent. Subsequently, the mixture was incubated at room temperature for $10 \mathrm{~min}$ and the absorbance at $540 \mathrm{~nm}$ was measured in a microplate reader. Fresh culture medium was used as a blank in every experiment. The quantity of nitrite was determined from a sodium nitrite standard curve.

\section{RESULT AND DISCUSSION}

\section{Effect of extracts on cells viability in Raw 264.7 macrophages}

In this study, we prepared crude extracts of three plants from Java Island, Indonesia: Curcuma aeruginosa Roxb, Morinda citrifolia and Apium graveolens to test their potential for antiinflammation activity. All the plant samples were macerated in $70 \%$ ethanol and evaporated to obtained viscous extracts. The cytotoxic effect of the extract was evaluated on macrophages RAW 264.7 cell lines using MTT method to ensure that the anti- 
inflammatory activity was not due to cytotoxicity effect from the extract. During inflammation, the ultimate phase of a series of signaling events, macrophages induce the expression of proinflammatory genes such as inducible nitric oxide synthase (iNOS). This enzyme is up-regulated secretion of pro-inflammatory cytokines, and produces NO from L-arginine. The regulation of NO production is therefore an important target for inflammatory disease. LPS stimulation alone has been demonstrated to induce iNOS transcription and its protein synthesis in murine macrophage RAW 264.7 cells, with a corresponding increase in NO production. Furthermore, LPS stimulation has also been shown to induce I $\kappa \mathrm{B}$ proteolysis and NF- $\kappa \mathrm{B}$ nuclear translocation (Xie, et al., 1994; Henkel, et al., 1993). Thus, this cell system is an excellent model for drug screening and the subsequent Evaluation of potential inhibitors against iNos and NO production.

We tested cytotoxicity assay of plants at concentration of $200 ; 100 ; 50 ; 25 ; 12.5 ; 6.25 \mu \mathrm{g} / \mathrm{mL}$. The result showed that all of extract have percentage of proliferation inhibition less than $50 \%$ at the highest concentration except for Curcuma aeruginosa Roxb. rhizome which showed 97\% inhibition at $200 \mu \mathrm{g} / \mathrm{mL}$ (Fig.1). It is indicated that all extract at concentration lower than $200 \mu \mathrm{g} / \mathrm{mL}$ did not give cytotoxicity effect in RAW 264.7 cell. Therefore, we used non-toxic at concentration $25 ; 50$ and $100 \mu \mathrm{g} / \mathrm{mL}$ to deterime its anti-inflammatory activity.

\section{Effect of Extracts on Nitrit Oxide Production in LPS-induced Macrophage}

Antiinflammation activity assay using LPS stimulated-RAW 264.7 cell was determined to quantify nitric oxide production after LPS induced. Extracts of plants were diluted with DMSO and Phosphate Buffer Saline (PBS) to obtain concentration at $25 ; 50$ and $100 \mu \mathrm{g} / \mathrm{mL}$. The Griess reaction, a spectrophotometric determination for nitrite, was carried out to quantify the nitrite levels in the conditioned medium of RAW 264.7 cells treated with LPS $2 \mathrm{ug} / \mathrm{mL}$. The final concentration of DMSO in the culture media was $0.2 \%$ and this concentration of DMSO did not show any effect on the cells. Sodium nitrate as a standard solution was tested separately to obtain standard curve of nitrate.

Table 1 shows the inhibitory activity by plant extracts towards NO production by LPS-activated macrophages.

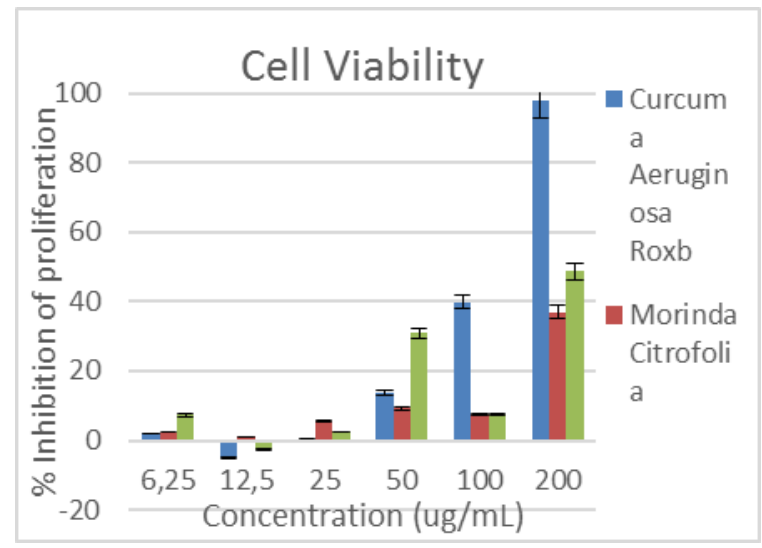

Figure I. Effects of Curcuma aeruginosa Roxb. rhizome, Morinda citrofolia fruit and Apium graveolens Leaf extracts on cell viability in Raw $\mathbf{2 6 4 . 7}$ mouse macrophage cells. Cell viability was tested by MTT reduction assays. Data were mean of three replications $x \pm S D(p<0,05)$ 
Table I.Nitrit oxide inhibition of Curcuma aeruginosa Roxb. rhizome, Morinda citrofolia Fruit, and Apium graveolens leaf extract

\begin{tabular}{clcc}
\hline No & Name of Extract & Concentration (ug/mL) & \% Inhibition \\
\hline I & Curcuma Aeruginosa & 25 & 84.426 \\
& Roxb Rhizome & 50 & 83.606 \\
2 & & 100 & 78.278 \\
& & 50 & 53.968 \\
& & 100 & 85.714 \\
3 & \multirow{2}{*}{ Aprinda citrofolia Fruit } & 200 & 85.714 \\
& & 50 & 0 \\
& & 100 & -146.72 \\
& & 200 & 18.852 \\
\hline
\end{tabular}

Based on this study, we can see that among of three extracts at each concentration, Morinda citrofolia fruit extracts showed the highest inhibition at $100 \mu \mathrm{g} / \mathrm{mL}$ and $200 \mu \mathrm{g} / \mathrm{mL}$, however Curcuma aeruginosa Roxb rhizome extract showed inhibition above $80 \%$ at lower concentration compared to Morinda citrofolia fruit extracts. In the other hand, Apium graveolens leaf extracts appeared to did not inhibit cells at all concentration. These results revealed that Curcuma aeruginosa Roxb. rhizome extract has better potential as antiinflammatory agent compared to another.

According to anti-inflammatory assay, Curcuma aeruginosa Roxb. rhizome and Morinda citrofolia fruit appeared to have antiinflammation effect. The ability of Curcuma aeruginosa Roxb. rhizoma and Morinda citrofolia fruit as antiinflammatory agent might be due to the presence of phenolic and flavonoid compounds or other phytochemicals such as terpenoid compound which could play a role as anti-inflammatory agents. In contrast, Apium graveolens did not show antiinflammation effect towards cell. This result might be related with Apium graveolens constituent that mostly containing of flavone glycoside (Apiin) which responsible for vasodilator activity.

To conclude, these data suggested that extracts from the plant species examined in this study deserve further investigation in order to isolate the bioactive secondary metabolites with antiinflammatory properties and also need inhibited determination of other pro-inflammatory cytokines such as inhibition of IL- 6 , TNF- $\alpha$.

\section{CONCLUSION}

We summarized that Curcuma aeruginosa Roxb. rhizome and Morinda citrifolia fruit show potency as antiinflammatory agents based on NO inhibition in LPS-induced RAW 264.7 cells.

\section{REFERENCES}

Cragg, G.M. and Newman, D.J., 2008, Detection, Isolation and Structural Determination in Bioactive Natural Products, 2nd Edition. Boca Raton: CRCpress.

Hendra, R., Ahmad, S., Oskoueian., E., Sukari, A. and Shukor, M.Y., 20II, Antioxidant, Antiinflammatory and Cytotoxicity of Phaleria macrocarpa (Boerl.) Scheff Fruit, BMC Complement. Altern. Med., I I, IO.

Hsieh, Y.H., Kuo, P.M., Chien, S.C., Shyur, L.F. and Wang, S.Y., 2007, Effects of Chamaecyparis formosensis Matasumura Extractives on lipopolysaccharide-induced Release of Nitric Oxide, Phytomedicine, I4(I0), 675-68.

Moncada, S., Palmer, R.M. and Higgs, E.A., I99I, Nitric Oxide: Physiology, Pathophysiology, and Pharmacology, Pharmacol. Rev., 43(2), 109-142.

MacMicking, J., Xie, Q.W. and Nathan, C., 1997, Nitric Oxide and Macrophage Function, Ann Rev. Immunol., I 5, 323-350.

Oh, J.H., Lee, T.J., Park, J.W. and Kwon, T.K., 2008, Withaferin A inhibits iNOS Ixpression and Nitric Oxide Production by Akt Inactivation and Down-Regulating LPS-induced Activity of NF-kappaB in RAW 264.7 Cells, Eur. J. Pharmacol., 599(I-3), I I-I7. 
Yang, E.J., Yim, E.Y., Song, G., Kim, G.O. and Gu Hyun, C., 2009, Inhibition of Nitric Oxide Production in Lipopolysaccharide-Activated RAW 264.7 Macrophages by Jeju Plant Extracts, Interdiscip. Toxicol.,2(4), 245-249.

Yoon, W.J., Kim, S.S., Oh, T.H., Lee, N.H. and Hyun, C.G., 2009, Abies Koreana Essential Oinhibits Drug-Resistant Skin Pathogen
Growth and LPS-Induced Inflammation of Murine Macrophage, Lipids, 44(5), 47I-476.

Wang, H. and Cao, Z.R., 20I4, Anti-inflammatory Effects of (-)-Epicatechin in Lipopolysaccharide-Stimulated Raw 264.7 Macrophages, Trop. J. Pharm. Res., 3(9), |4|5-14|9. 